\title{
Analisis Konsistensi Atribut Karakter Desain untuk Menentukan Ciri Khas Sebuah Merek Produk: Studi Kasus pada Sepatu Converse
}

\author{
Bambang Tristiyono, Syahrul Hidayatullah, Syawalrizqi Iqbal Abdurrahim, dan Sasha Amanda Savhira \\ Departemen Desain Produk, Fakultas Arsitektur Desain dan Perencanaan \\ Institut Teknologi Sepuluh Nopember (ITS) \\ Email : gacombi@prodes.its.ac.id
}

\begin{abstract}
Abstrak-Pentingnya ciri khas sebuah produk dan merek telah menjadi identitas bisnis yang menarik untuk meningkatkan nilai produk. Situasi tersebut menjadikan persaingan produk semakin kompetitif dalam hal kinerja teknis, fungsi, dan karakter desain, meliputi: bentuk, warna, dan bahan yang dipilih. Hal ini menegaskan bahwa penciptaan bahasa desain yang tepat, telah menjadi strategis dalam persaingan produk yang menjadi perwujudan identitas merek. Desain telah menjadi alat kompetitif yang efektif bagi perusahaan dalam memenangkan persaingan pasar. Tampilan merek dan produk yang khas secara visual telah menjadi faktor penentu dalam memenangkan persaingan berbagai kategori produk. Perusahaan terus mengembangkan produk dengan desain yang tidak hanya tampil menarik tetapi juga mempunyai karakter khusus sebagai cirikhas merek produk, sebagai cerminan nilai-nilai inti produk tersebut. Riset ini bertujuan untuk mengidentifikasi isyarat desain, seperti bentuk, tekstur, serta warna yang digunakan oleh konsumen untuk menyimpulkan atribut yang menjadi identitas dan karakter dari suatu merek. Riset ini menggunakan studi kasus pada merek sepatu Converse, karena merupakan produk yang laris dan sudah banyak dikenal masyarakat sejak lama. Metode penelitian mengggunakan kuisioner sebagai alat ukur, yang dibuat secara kualitatif. Kuisioner yang disebarkan secara online, jumlah sampel yang diambil adalah sebanyak 77 responden.
\end{abstract}

Kata kunci: Karakter desain, ciri khas, merek

Abstract - The importance of the characteristics of a product and brand has become an attractive business identity to increase product value. This situation makes product competition more competitive in terms of technical performance, functions, and character design, including: the shape, colour, and material chosen. This confirms that the creation of the right design language has become a strategic product competition that embodies brand identity. Design has become an effective competitive tool for companies in winning market competition. The appearance of visually distinctive brands and products has become a determining factor in winning competition in various product categories. The company continues to develop products with designs that not only look attractive but also have special characteristics as a distinctive brand of the product, as a reflection of the core values of the product. This research aims to identify design cues, such as shapes, textures, and colours used by consumers to deduce attributes that are the identity and character of a brand. This research using case studies on Converse shoe brands, because it is a best-selling product and has been widely known to the public for a long time. The research method uses questionnaires as a measurement tool, which is made qualitatively. Questionnaires distributed online, the number of samples taken was 77 respondents.

Keyword: Character design, design cues, brand

\section{PENDAHULUAN}

Merek (brand) berfungsi mengidentifikasi barang atau jasa dari individu atau kelompok yang membedakannya dari produk sejenis lainnya [1]. Lebih dari itu, merek adalah sesuatu yang dibentuk dalam pikiran pelanggan dan memiliki kekuatan membentuk kepercayaan pelanggan [2]. Jika perusahaan mampu membangun merek yang kuat di pikiran pelanggan melalui strategi pemasaran yang tepat maka perusahaan akan mampu membangun mereknya menjadi kuat dan semakin kuat. Dengan demikian, merek dapat memberi nilai tambah produk yang ditawarkan kepada pelanggannya yang dinyatakan sebagai ekuitas merek [3].

Merek-merek ternama selalu menggunakan metode desain secara spesifik dan konsisten diterapkan pada produk mereka. Melalui konsistensi desain, dapat membantu menguatkan perbedaan yang terlihat dari pesaing. Produk diferensiasi adalah apa yang membuat merek menjadi lakuatau lemah [4].

Mengembangkan pengakuan merek membutuhkan lebih dari satu produk. Untuk menciptakan identitas yang khas dan menjaganya secara terus menerus, perusahaan perlu memelihara konsistensi visual dan berkelanjutan pada generasi produk yang berurutan. Konsistensi pada dasarnya sudah melekat dalam definisi atas usulan gagasan konsep dan , teridentifikasi aplikasinya dalam varian produknya [5].

Semakin beraneka ragam merek-merek sepatu yang beredar di pasaran, mendorong konsumen untuk lebihpintar dan lebih cermat lagi dalam memutuskan pemilihan produk yang diharapkan. Konsumen beranggapan bahwa merek yang terkenal di pasaran lebih bagus dan lebih berkualitas dibandingkan dengan merekyang kurang populer di pasaran. Merek yang populer di pasaran memberikan informasiyang 
lengkap dibandingkan produk dengan merek yang cenderung tertinggal di pasaran. Perusahaan juga memerlukan informasi tentang faktor-faktor yang dapat mempengaruhi konsumen dalam melakukan keputusan pembelian suatu produk, diantaranya faktor yang turut berperan dalam pengambilan keputusan pembelian konsumen seperti kualitas produk (product quality) dan citra merek (brand image) suatu produk [6].

Penelitian ini bertujuan menganalisis karakter desain (design cue) yang dimiliki produk Converse melalui preferensi responden. Responden adalah usia remaja akhir dan dewasa awal. Sehingga nantinya dapat diketahui apa saja faktor eksplisit dan implisist design cue pada produk sepatu Converse tersebut.

\section{METODE}

Metode yang digunakan dalam penelitian ini adalah sebagai berikut:

\section{Studi Literatur}

Studi ini bertujuan untuk menganalisis bentuk serta aspek desain yang merupakan ciri khas dan karakter dari produk sepatu Converse melalui sumber yang berasal dari beberapa jurnal, buku dan website. Dari beberapa sumber tersebut akan didapatkan data-data mengenai sepatu Converse serta penjelasan mengenai atribut khas dalam sebuah produk tersebut yang nantinya dapat digunakan sebagai acuan data dalam membuat kisi-kisi pertanyaan kuisioner.

Beberapa aspek desain yang menjadi fokus dalam studi ini antara lain: logo, desain sol, bentuk toe, warna dan material. Studi ini menghasilkan beberapa analisa bentuk karakter desain yang terdapat pada setiap seri produk sepatu Converse. Hasil dari studi literatur ini kemudian menjadi dasar rancangan pertanyaan kuisioner yang akan dikonfirmasikan kepada responden.

\section{Riset Konsumen}

Metode selanjutnya yang digunakan adalah riset konsumen melalui penyebaran kuisioner. Responden yang dituju adalah usia remaja akhir dan dewasa awal (pembagian usia menurut Departemen Kesehatan RI). Masa usia remaja akhir adalah 17-25 tahun sedangkan masa usia dewasa awal adalah 26-35 tahun. Hal tersebut didasari alasan bahwa pada usia dewasa awal, orang sudah mulai bisa mengambil keputusan untuk membeli suatu barang dan pada rentang usia tersebut seseorang cenderung mengikuti trend serta ingin mengekspresikan diri.

Proses riset dengan menyebarkan kuisioner secara online untuk mengetahui atribut karakter desain apa saja yang paling khas dari produk sepatu Converse menurut responden. Kuisioner ini disebarkan melalui beberapa platform media sosial, diantaranya adalah Facebook, Twitter, Instagram, dan Line. Hasil dari kuisioner ini dipilah dan diolah secara kualitatif untuk mendapatkan rekap data keseluruhan.

Pertanyaan-pertanyaan dirancang menjadi tiga kelompok pertanyaan yang meliputi; karakteristik responden, bentuk dan desain khas dari Converse, serta pertanyaan mengenai brand loyalitas. Berikut adalah skenario rancangan kelompok pertanyaan-pertanyaan tersebut: a. Karakteristik responden yang menjadi pengguna Sepatu Converse, meliputi; demografi dan psikografinya.

b. Penilaian bentuk dan desain yang menjadi ciri khas dari sepatu Converse, ditinjau dari aspek-aspek desain berikut: logo, desain sol, bentuk toe, warna dan material.

c. Faktor kognitif, afektif, dan evaluatif konsumen dalam memilih produk Sepatu Converse.

\section{HASIL RISET DAN PEMBAHASAN}

Dari hasil riset konsumen yang sudah dilakukan, melalui penyebaran kuisioner pada 77 responden berusia 17-25 tahun, didapatkan data-data sebagai berikut:

\section{A. Karakter Responden.}

\section{Jenis kelamin.}

Dari 77 responden, 69\% adalah pria. Menunjukan bahwa user dari sepatu Converse lebih banyak pria dibanding wanita, seperti kenyataannya Converse lebih relevan dengan lifestyle kaum pria.

\section{Usia saat ini.}

Dari jumlah responden yang sama, hampir 90\% responden berusia 17-25 tahun. Hasilrisetmenunjukkan data sudahvalid, rentang usia tersebut sangat sesuai untuk target market sepatu Converse, dengan toleransi error $10 \%$.

\section{Pekerjaan saat ini.}

Dari 77 responden, 81\% -nya adalah pelajar dan mahasiswa. 55\% responden memiliki uang saku Rp.500.000,- - Rp. 1.500.000,-. 35\% memiliki uang saku diatas Rp. 1.500.000,- dan sisanya memiliki uang saku dibawah Rp. 500.000,-. Menunjukan responden kuisioner Converse kebanyakan adalah kalangan menengah, sesuai dengan target tim. Hal tersebut jug arelevan dengan kesukaan tentang musik. Hasil kuisioner menunjukan 48\% responden suka genre musik Indie, diposisi kedua dan ketiga dengan presentase yang sama yaitu 14\% ditempati oleh responden dengan genre musik $\mathrm{RnB}$ dan musik House. Diposisi keempat dengan presentase yang jauh yaitu 3\% dengan genre musik pop, sisanya $1 \%$ dengan genre musik yang bermacam-macam. Mereka adalah user yang mengikuti trend dan cenderung mengekspresikan style mereka pada lingkungannya.

\section{Memiliki sepatu Converse.}

Dari 77 responden menunjukan 90\% responden memiliki sepatu Converse. Presentase responden dengan kepemilikan lebih dari tiga adalah 20\%. Presentase responden dengan kepemilikan tiga pasang adalah 15\%. Kemudian 31\% dengan kepemilikan dua pasang sepatu, lalu sepasang sepatu dengan presentase yang sama yaitu $31 \%$. Jumlah ini sudah memenuhi target untuk melanjutkan pada tahap inti kuisioner design cue sepatu Converse. Kepemilikan sepatu Converse responden juga sudah cukup lama, jadi dapat disimpulkan responden yang dituju sangat tepat, karena bukan pembeli baru yang masih belum kenal merek tersebut. 39 responden sudah menggunakan converse lebih dari 2 tahun. Responden dengan penggunaan 1-2 tahun berjumlah 16, dan 6 bulan-1 tahun berjumlah 10 responden. Lama kepemilikan yang memenuhi kriteria yaitu pada rentang 1-2 
tahun dan lebih dari 2 tahun. Pada rentang tersebut responden pasti sudah memahami sepatu yang ia pakai sebagai perwujudan citra dirinya.

5. Sejauh mana memahami varian produk Converse.

Dari 75 responden, $58 \%$ atau 44 responden menyatakan biasa saja. Responden yang sangat paham berjumlah $16 \%$ atau 12 responden, sedangkan yang kurang paham dan tidak tahu berjumlah 20 responden. Sehingga dapat disimpulkan bahwa mayoritas responden cukup paham pada varian dan fitur produk converse.

6. Mempertimbangkan faktor citra diri dan gengsi dalam membeli sepatu Converse.

Dari hasil kuisioner menunjukan 74\% setuju dengan argumen diatas. Dapat disimpulkan bahwa Converse sudah memiliki brand identity yang kuat. Responden tidak hanya membeli untuk fungsi dasar produk yaitu sebagai alas kaki, tetapi untuk juga mempertimbangkanfungsi simbolik yaitu sebagai alat mengekspresikan diri dan menunjukan citra diri.

\section{B. Tentang Penilaian Produk.}

Pembahasan berikut adalah hasil-hasil respons konsumen tentang penilaian produk sepatu Converse.

\section{Bentuk toe tertera pada setiap keluaran Converse.}

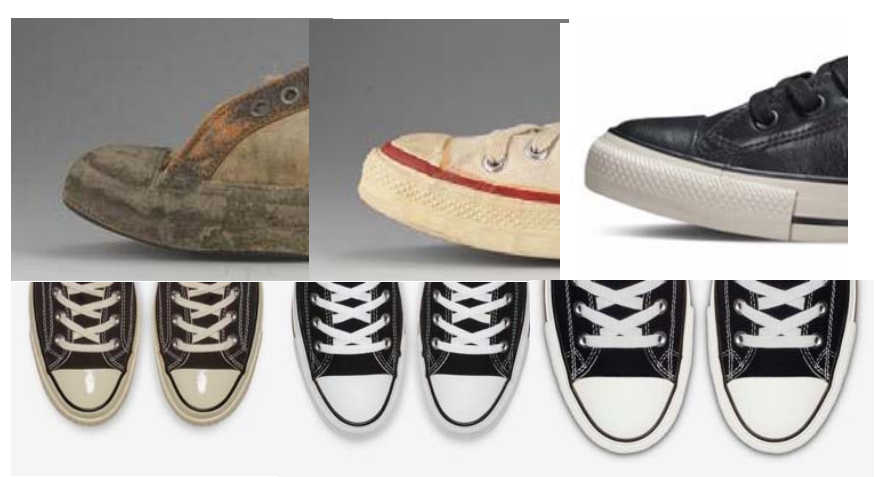

Gambar 1. Bentuk Toe varian sepatu Converse. (Sumber: Olahan Penulis)

Berdasarkan hasil dari kuisioner, 39 responden atau lebih dari 50\% jumlah keseluruhan responden menyatakan setuju bahwa bentuk toe tersebut selalu tampil pada setiap produk sepatu Converse. Sedangkan 18 responden menyatakan sangat setuju dan sisanya adalah yang merasa biasa saja atau kurang setuju terhadap pernyataan yang disebutkan. Maka dapat disimpulkan bahwa mayoritas responden sepakat bahwa bentuk toe pada tiap seri keluaran converse selalu serupa. Konsistensi bentuk toe converse (gambar 1) dari keluaran seri pertama yaitu pada tahun 1908, membuat bentuk toe converse menjadi ciri khas desainnya. Oleh sebab itu jika ada sepatu yang memiliki bentuk toe serupa dengan converse, hal itu pasti terinspirasi oleh bentuk toe pada converse.

2. Bentuk soles tampil sama pada setiap keluaran serinya.

Berdasarkan hasil kuisioner, 31 responden sangat setuju bahwa bentuk soles (gambar 2) converse selalu tampil serupa dalam tiap seri yang dikeluarkannya. Sedangkan 27 responden setuju, 15 responden biasa saja, dan 4 responden kontra dengan pernyataan. Hal ini dapat disimpulkan bahwa mayoritas (58 responden) sepakat, bentuk soles pada converse menjadi salah satu identitas dan ciri khasnya karena konsistensinya dari awal keluaran seri pertama.
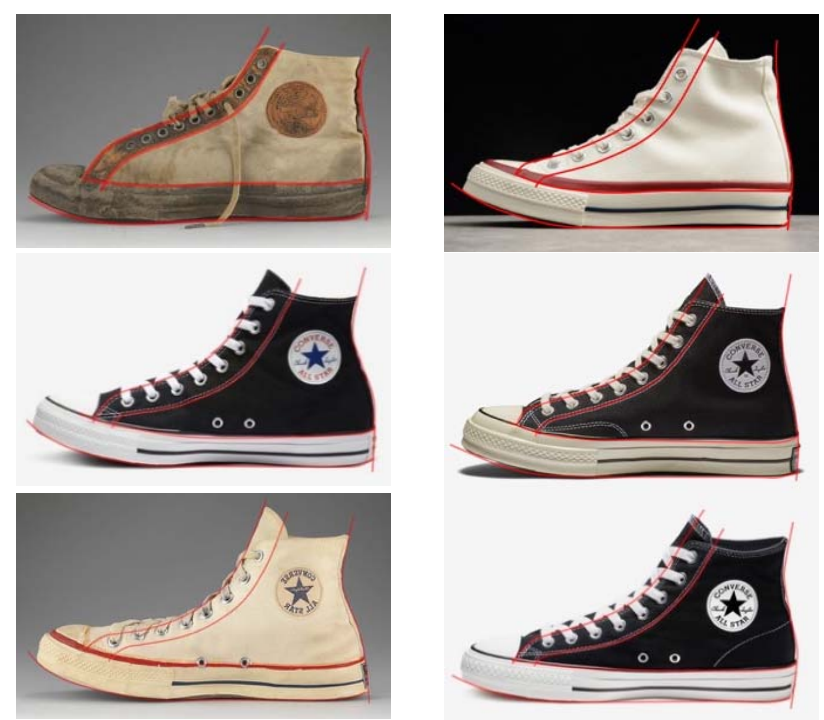

Gambar 2. Bentuk Soles varian sepatu Converse. (Sumber: Olahan Penulis)

\section{Konsistensi Logo.}
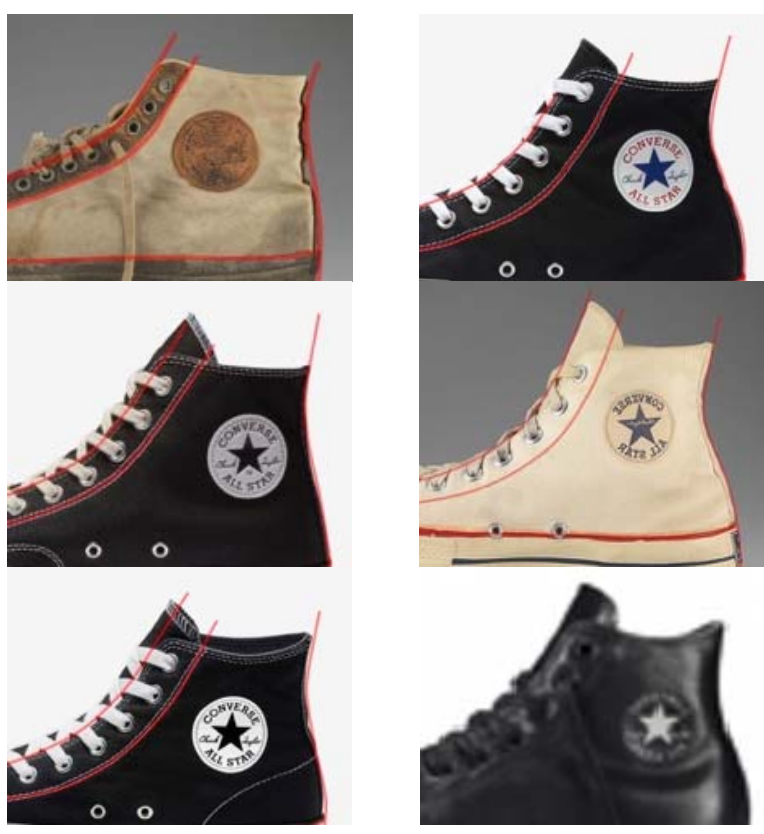

Gambar 3. Logo pada varian sepatu Converse. (Sumber: Olahan Penulis)

Converse memiliki logo yang sangat khas. Logo tersebut senantiasa tertera pada produk-produk sepatu yang dikeluarkan oleh Converse (gambar 3). Dari 77 responden, 29 responden setuju dengan pernyataan tersebut, 20 responden menyatakan sangat setuju, 15 responden menyatakan biasa saja, 7 responden menyatakan kurang setuju, dan 6 responden menyatakan sangat tidak setuju. Sehingga dari hasil tersebut dapat disimpulkan bahwa mayoritas responden (lebih dari 50\%) menyatakan setuju bahwa aplikasi logo Converse selalu tertera pada setiap produk sepatunya. Dapat disimpulkan bahwa converse juga 
konsisten memunculkan logo-nya pada tiap seri produknya. Logo dengan bintang pada sepatu seri high, dan logo type pada sepatu seri low.

4. Warna cenderung dusty merupakan ciri khas converse.

Kebanyakan produk sepatu keluaran Converse memiliki warna yang cenderung dusty atau warna yang memiliki hint abu-abu. Hal tersebut merupakan ciri khas dari produk Converse. Namun pada pernyataan ini, 25 responden menyatakan setuju, 17 responden menyatakan sangat setuju, sedangkan 24 responden menyatakan biasa saja, dan sisanya menyatakan pernyataan tersebut kurang sesuai. Menilik pernyataan-pernyataan sebelumnya, mayoritas responden memang banyak yang sepakat bahwa warna dusty adalah ciri khas Converse, namun banyak juga responden yang merasa biasa saja terhadap pernyataan mengenai warna tersebut. Hasil kuisioner tidak memantapkan argumen bahwa warna dusty merupakan salah satu ciri khas converse.

5. Warna basic membuat converse tidak lengkang oleh jaman.

Berdasarkan hasil kuisioner, 34 responden setuju dan 29 responden sangat setuju bahwa warna basic membuat converse tidak habis dimakan jaman. Sedangkan 14 responden tidak mendukung pernyataan tersebut. Dapat disimpulkan bahwa warna basic pada converse membuat produk converse menjadi timeless atau tidak lengkang waktu (gambar 4). Hal ini terbukti dengan masih banyak pengguna dari produk sepatu ini.

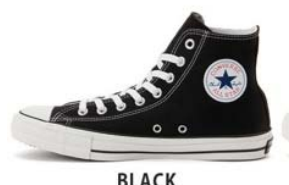

BLACK
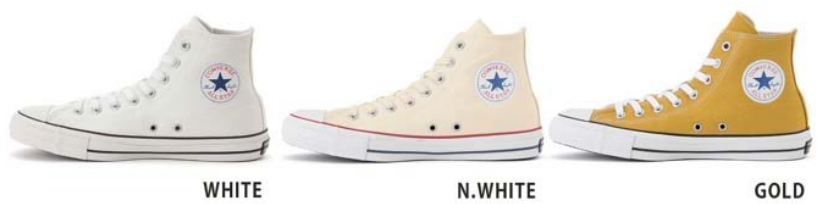

Gambar 4. Warna basic pada varian sepatu Converse. (Sumber: Olahan Penulis)

\section{Material canvas menjadi ciri khas Converse}

Sepatu Converse dengan material kanvas adalah yang paling banyak digunakan dan ditemui di pasaran, meskipun ada juga beberapa produk Converse yang menggunakan material kulit. Dari data yang didapat dari kuisioner, mayoritas responden (41 responden setuju dan 23 responden sangat setuju) menyatakan sepakat bahwa material kanvas merupakan ciri khas Converse (gambar 5). Hal ini juga membuktikan bahwa material kanvas sudah melekat pada image produk Converse. Converse juga menjadi brand yang konsisten dengan sepatu kanvas pertama dibanding pesaingnya yaitu Superga, Keds, dan Vans.

\section{Material canvas membuat kesan polos}

Dari hasil penilaian responden, dapat dilihat bahwa lebih dari 50\% setuju bahwa pemilihan material kanvas pada converse menambah kesan polos pada converse. $30 \%$ responden sangat setuju dengan pernyataan tersebut. Sedangkan $18 \%$ responden tidak mendukung pernyataan tersebut. Kesan polos membuat converse dapat menyesuaikan trend di tiap periode tahun.
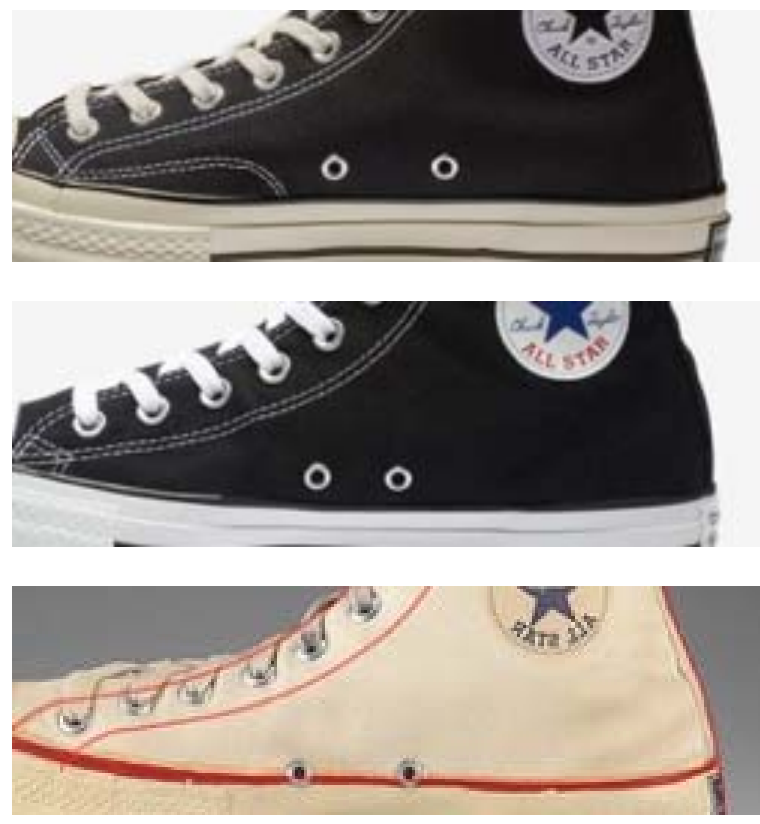

Gambar 5. Material canvas pada varian sepatu Converse. (Sumber: Olahan Penulis)

C. Penilaian Faktor Kognitif, Afektif, dan Evaluatif Konsumen

1. Merek yang kuat

Pada era sekarang ini, hampir setiap orang, terutama kawula muda pasti kenal dengan produk Converse. Hal ini juga yang mempengaruhi keputusan pembeli untuk memilih sepatu Converse. Pada pernyataan ini 32 responden menyatakan setuju dan 17 responden menyatakan sangat setuju. Sehingga dapat disimpulkan bahwa mayoritas responden sepakat bahwa Converse adalah produk terkenal dan mereka memperhatikan faktor kekuatanmerek saat memilih sepatu Converse. Setelah perjalan panjang Converse selama satu abad, sepatu Converse sudah memiliki nilai reflektif, yaitu jika memakai sepatu converse maka user telah menjadi bagian dari suatu "komunitas". Sehingga dapat disimpulkan bahwa Converse mempunyai karakter merek yang kuat dan selalu tampil dengan ciri khas yang konsisten.

\section{Mudah dibeli dimana saja baik offline ataupun online}

Berdasarkan hasil kuisioner, 58 responden (lebih dari 70\% responden) setuju bahwa converse mudah ditemukan dan dibeli baik di kota maupun desa, offline maupun online. Sedangkan 11 responden biasa saja, dan 7 responden kontra dengan pernyataan tersebut. Dapat disimpulkan bahwa semua kalangan dapat menemukan sepatu Converse, tidak seperti barang ekslusif yang hanya bisa ditemukan oleh beberapa kalangan saja.

\section{Saya suka Converse}

Dari keseluruhan jumlah responden, 30 responden menyatakan mereka setuju dan menyukai sepatu merek Converse, 24 responden sangat setuju, 16 responden merasa 
biasa saja, 2 responden tidak setuju dan 3 responden sangat tidak setuju atau sangat tidak menyukai produk Converse. Hal ini mengindikasikan kepuasan mayoritas responden sehingga menyukai produk Converse karena sesuai dengan karakter dan identitas mereka.

\section{Enggan membeli sepatu merek lain}

Berdasarkan hasil kuisioner, $11 \%$ responden sudah menjadi fanatik converse yang tidak akan membeli sepatu merek lain selain converse. $12 \%$ responden setuju dengan pernyataan. $40 \%$ responden menyatakan biasa saja yang menandakan masih memberi kesempatan pada merek lain. Sedangkan $31 \%$ responden kontra dengan pernyataan yang diajukan. Dapat disimpulkan bahwa argumen ini tidak valid. Dari hasil kuisioner user mayoritas memilih biasa saja, yang artinya bahwa user tetap ingin memiliki sepatu merek lain.

5. Memiliki varian warna dan desain yang mampu memenuhi keinginan dan selera.

Sepatu Converse memiliki banyak variasi warna dan desain. Hal tersebut bertujuan untuk memenuhi keinginan dan selera konsumen. Mayoritas responden setuju terhadap pernyataan ini. Terbukti dengan lebih 50\% responden sepakat, dengan rincian sebanyak 41 responden menyatakan setuju dan 13 responden merasa sangat setuju. Hal tersebut terbukti Sepatu Coverse selalu diminati masyarakat dari waktu kewaktu ditengah persaingan bisnis sepatu yang semakin kompetitif.

\section{KESIMPULAN}

Dari pembahasan diatas berdasarkan riset konsumen yang telah dilakukan, beberapa karakter desain (design cue) sepatu Converse yang dapat disimpulkan sebagai ciri khas produk adalah sebagai berikut:

1. Bentuk Toe menjadi salah satu ciri khas yang kuat dari converse. Konsistensi bentuk toe converse dari keluaran seri pertama yaitu pada tahun 1908, membuat bentuk toe converse menjadi ciri khas desainnya. Oleh sebab itu jika ada sepatu yang memiliki bentuk toe serupa dengan converse, hal itu pasti terinspirasi oleh bentuk toe pada sepatu converse.

2. Begitupula dengan desain soles pada converse, memiliki konsistensi dari awal keluaran seri pertamanya sampai sekarang. Dengan konsistensi desain soles yang sangat khas membuat bagian soles pada Converse menjadi ciri khas produk tersebut.
3. Pengaplikasian logo juga menjadi salah satu ciri khas Converse. Konsisten memunculkan logonya pada tiap seri produknya, membuat orang awam dapat mengidentifikasi bahwa itu sepatu Converse. Logo dengan bintang pada sepatu tipe high, dan logotype pada sepatu tipe low.

4. Warna juga menjadi salah satu ciri khas sepatu Converse. Warna basic pada sepatu Converse membuat ia timelessatau tidak lengkang oleh jaman. Oleh karena itu sepatu Converse konsisten dengan warna-warna basic pada tiap serinya.

5. Material canvas juga sudah melekat menjadi ciri khas sepatu Converse. Konsistensi sepatu Converse memakai material kanvas pada produknya menjadikan Conversebrandpertama yang konsisten dengan sepatu kanvas dibanding pesaingnya yaitu Superga, Keds, dan Vans.

Brand identity secara langsung dan tidak langsung juga mempengaruhi keputusan pembelian konsumen terhadap sepatu Converse. Produk sepatu Converse memiliki konsistensi atribut yang cukup baik. Hal ini menunjukkan bahwa pesan yang disampaikan pada konsumen melalui program pemasarannya selalu konsisten. Selain itu ciri khas dari produk ini sendiri juga sudah tertanam di pikiran konsumen.

\section{DAFTAR PUSTAKA}

[1] Wahyuni, Astuti, S. dan Cahyadi, I. G., "Pengaruh Elemen Ekuitas Merek Terhadap Rasa Percaya Diri Pelanggan Di Surabaya Atas Keputusan Pembelian Sepeda Motor Honda", Jurnal Ekonomi dan Bisnis Airlangga-JEBA, 17-2, 2007.

[2] Peter, J. P., \& Olson, J. C., "Understanding consumer behaviour", Irwin Professional Publishing, 1996.

[3] Aaker, D. A., "Managing Brand Equity: Capitalizing on the Value of a Brand Name", New York, 1991.

[4] Karjalainen, T. M., "It looks like a Toyota: Educational approaches to designing for visual brand recognition", International Journal of Design, 1(1), 2007.

[5] Krippendorff, K., "The semantic turn: A new foundation for design", CRC Press, 2005.

[6] Supriyadi, S., Wiyani, W., \& Nugraha, G. I. K., "Pengaruh Kualitas Produk dan Brand Image Terhadap Keputusan Pembelian", Jurnal bisnis dan manajemen, 4(1), 2017. 